\title{
Research on Personnel Training Mode of Business Administration Major Based on OBE
}

\author{
Ting Liu*
}

Huizhou Economics and Polytechnic College, Huizhou 516000, China. Email: 983964492@qq.com

\begin{abstract}
The establishment of teaching and scientific literacy training for business administration majors in universities is not only related to the implementation quality and level of teaching for business administration majors in universities, but also has an important impact on the training of applied talents in China. In the strategy of rejuvenating the country through science and education, we should not only explain theoretical knowledge in teaching, but also pay attention to the improvement of students' practical ability and knowledge application ability, especially in higher vocational colleges, so as to provide high-quality talents for the development of various undertakings in China. Cultivating high-level and high-quality innovative talents is an important mission shouldered by colleges and universities, and it is also an urgent need of the development of the times. This paper draws lessons from the advanced educational idea of results-oriented education, and discusses how to improve the teaching quality, students' professional skills and students' adaptation to the future working environment through OBE (Outcome-Based Education) teaching mode, so as to find out a teaching mode that is more suitable for improving the professional core competence of college business administration students.
\end{abstract}

Keywords: Business Administration; OBE; Personnel Training

\section{Introduction}

OBE is the abbreviation of outcome based education. It is an advanced educational concept which emphasizes that under the premise of clear learning objectives, students actively participate in learning and pay attention to the cultivation of students' professional quality and acquisition of professional skills ${ }^{[1]}$. With the rapid development of network information technology, the marketing environment of enterprises and the concept, behavior and mode of consumers have undergone unprecedented changes ${ }^{[2]}$. In this context, it puts forward new challenges to the talent training of Business Administration Major in Colleges and universities. From the current situation of information management professional personnel training in Colleges and universities, it can be seen that the professional ability of information management graduates cannot meet the actual needs of society under the traditional education concept and training mode, which causes the mismatch between the professional talents of information management and social needs ${ }^{[3]}$. Business Administration Major of university is committed to training professional talents with certain basic management ability, ability to find and solve problems, ability to analyze problems, ability to give feasible and reasonable solutions according to specific problems, team communication ability, lifelong learning ability and other related abilities for enterprises and society ${ }^{[4]}$. It is particularly important and necessary to actively explore the practical teaching reform of Business Administration Specialty Based on the OBE education concept, and to build a practical teaching system of business admission specialty that meets the needs of the industry and enterprises ${ }^{[5]}$.

This is an open-access article distributed under the terms of the Creative Commons Attribution Non-Commercial License (http://creativecommons.org/licenses/by-nc/4.0/), which permits unrestricted non-commercial use, distribution, and reproduction in any medium, provided the original work is properly cited. 
With the rapid development of social economy, the cultivation of innovative talents is becoming increasingly important and urgent. In the era of Internet big data, higher requirements and challenges are put forward for the cultivation of information management professionals. The information management major is an interdisciplinary subject, which requires students' cross-border integration, innovation ability and practical application ability ${ }^{[6]}$. OBE education mode is the practical requirement of China's higher education to adapt to the development needs of the times, and it's the only way to cultivate high skilled and high-quality professional talents for Business Administration Major in colleges and universities under the background of big data ${ }^{[7]}$. The era of Internet big data has put forward new requirements for the cultivation of information management professionals in colleges and universities. The traditional training mode of information management major needs corresponding reform. In the strategy of rejuvenating the country through science and education, we should not only explain the theoretical knowledge in teaching, but also pay attention to the improvement of students' practical ability and knowledge application ability, so as to provide high-quality talents for the development of various undertakings in China ${ }^{[8]}$. Based on the advanced educational concept of achievement oriented education, this paper discusses how to improve the teaching quality and students' vocational skills and make students adapt the future working environment through the OBE concept teaching mode, so as to explore a teaching mode more suitable for the promotion of professional core competence of business administration majors.

\section{Visualized results of practical teaching reform of business administration major under the concept of OBE}

Learning achievement and learning output are especially emphasized in OBE educational philosophy, which are the relatively lacking links in Chinese higher education. In recent years, all colleges and universities are actively exploring multi-dimensional talent training programs of application-oriented teaching and practical teaching due to the change of talent demand of society and enterprises. In the measurement and achievement of learning outcomes, OBE results orientation pays more attention to the specific situation of individuals, and makes analysis and comparison from the vertical level, which is a reflection of students' progress after a certain learning process and steps are completed. The purpose of practical teaching of business administration major is to cultivate students' qualities and skills that meet the needs of enterprises and society. Therefore, the practical teaching conducted by introducing OBE education concept will aim at the final results, and reverse derivation will be made from the goal to design the practical teaching scheme with realize ability and goal. Innovative talents are not only good at breaking the inherent mindset, opening up new ideas and flexibly thinking about the path to solve problems, but also applying new ideas to practical work and making new achievements. Considering that the practice teaching of business administration major is mainly based on simulation, it is more necessary to design the practice teaching process scientifically, pragmatically and efficiently, and the setting of practice teaching content should be fully integrated with the industry and connected with the actual posts, so as to meet the actual needs of the industry and enterprises ${ }^{[9]}$. On the basis of OBE educational philosophy, it is an ideal way to realize practical teaching by exchanging the positions of teachers and students, taking students as the center, and making teaching plans and teaching schemes that meet students' goals. OBE concept education model can transform this theoretical knowledge into practical ability that students can master it. And at the same time, in the process of assessing teaching achievements, it can reflect the true situation of students' learning achievements by constructing diversified assessment models.

The important idea of OBE concept is to emphasize continuous improvement, which requires the continuity of improvement that should be reflected in all links and levels of teaching, and the result orientation of teaching should be emphasized. In the practical teaching of business administration major, schools and teachers should take into account all the factors that affect the practical teaching activities, recognize the present situation of practical teaching, find out the problems of practical teaching and find out the rules of practical teaching. OBE educational philosophy aims at students' learning achievements and cultivates students' learning goals. Therefore, according to the requirements of business administration training objectives, in the ideological and political reform of management, project management and other courses, the OBE concept is based on students' achievement-oriented curriculum design, and the business admin- 
istration training standards reached by students are clearly defined. In OBE teaching philosophy, periodic achievements evaluation and feedback can be carried out, so that problems in practical teaching can be timely corrected and irreversible achievements mistakes can be avoided. Such ideas and practices are also in line with the working standards of enterprises and the requirements for employees, so they have important guiding significance for practical teaching or theoretical teaching.

\section{Suggestions on promoting practice teaching reform of business admin- istration specialty based on OBE concept}

\subsection{Strengthen the horizontal cooperation of industry, university and research institute}

The purpose of practical teaching is to meet the needs of society and enterprises for talents. Therefore, the construction of practical teaching should be combined with enterprises and employers to build production, teaching and research projects, so as to achieve a targeted goal and cultivate practical talents who can meet the needs of enterprises and society. Nowadays, the ratio of students to teachers in Colleges and universities is unreasonable, especially in the case of serious shortage of double qualified teachers, it is difficult for the school to carry out fine management of the practice teaching process. The effective solution is to fully mobilize the enthusiasm of students to participate in the process of practical teaching and improve their ability of self-management. The training goal is the basic basis for constructing professional knowledge structure, forming curriculum system and carrying out teaching activities. In the Internet era, with the rapid development of information technology, business management major also needs innovative talents who are good at dealing with the era of big data ${ }^{[10]}$. Therefore, the practice teaching of business administration can help build the platform of "Internet plus education", give full play to the advantages of low cost, strong interactivity and high integration of resources in Internet information technology, and innovate the practice teaching mode and method. In order to better assist the professional teachers to improve the teaching level and students' learning effect, it is necessary to make full use of the OBE education mode.

Based on the OBE teaching concept, the reconstruction of practical teaching results should be carried out from the perspective of the cultivation of students' professional knowledge application ability and professional quality. In the process of explaining knowledge to students, students should be able to understand, remember and master the scientific process of the corresponding knowledge. In the actual teaching process, teachers should also pay attention to the optimization of their own teaching methods and methods. In practice, teachers should change the situation of passive teaching. Therefore, it is necessary for colleges and universities to systematically construct the growth program system of each student, so as to be able to effectively focus on students and formulate practical teaching programs that meet their own conditions and social needs. In the evaluation mechanism, we can also increase the way of students' self-evaluation and mutual evaluation. Through multi-angle assessment and evaluation, we can get more objective student learning results.

\subsection{Enrich practice teaching environment}

The practical teaching of business administration major in colleges and universities must be able to follow the actual market environment before it has practical significance. Therefore, the school or the major should actively sign practice and practice bases with various types of enterprises and units. The main purpose of talent training in universities is to provide more skilled talents for the society. In order to achieve this goal, teachers should fully supplement the missing knowledge in books in the process of explaining the theories of business administration. Traditional practice teaching mainly focuses on teacher evaluation, and the evaluation subject is relatively single. To a certain extent, the result in the subjectivity of evaluation cannot play a good role in evaluation. The ultimate goal of practical teaching of business administration major is to improve students' professional ability and overall quality, and make student be competent for various social and enterprise requirements in the future ${ }^{[11]}$. However, at present, most of the business administration teaching and practice teaching adopt a one-size-fits-all approach to students' assessment, which lacks 
staged and diversified assessment, and cannot simply measure students' learning ability and personal comprehensive quality by their academic achievements. According to OBE's educational philosophy, in the evaluation process of practical teaching, business administration majors should establish a whole process, a diversified and open evaluation system to realize a comprehensive, fair and objective evaluation of students' practical ability.

Enterprises should consider consumers' behavior in the process of formulating and implementing marketing strategies, and regard it as the core of marketing strategies. Table 1 shows the correspondence between marketing elements and consumers.

Table 1. Correspondence between marketing elements and consumers

\begin{tabular}{|l|l|}
\hline Marketing requirements & Consumer issues \\
\hline Products & Can the product meet the needs of consumers \\
\hline Promotion & How to promote consumers' desire to buy \\
\hline Pricing & How does price promote consumption behaviour \\
\hline Channel & The influence of channels on consumers' purchase behaviour \\
\hline
\end{tabular}

In the process of classroom teaching design, based on the result-oriented thinking of OBE concept, appropriate teaching methods and means are selected for courses with different contents and properties to ensure the realization of training objectives. In the actual operation process, teachers' evaluation methods and status remain unchanged, but in terms of evaluation content, students' evaluation mechanism is added. Through students' self-evaluation and mutual evaluation, students' participation enthusiasm can be fully mobilized to help them improve their thinking ability and judgment level. The reform of evaluation system should be a process of continuous improvement. According to the training objectives and graduation requirements, the teaching and evaluation system should be constantly revised and improved through feedback information such as teaching and practice links. The curriculum of business administration majors organizes the teaching contents according to the logical structure of disciplines. The basic courses account for a large proportion, while the professional courses account for a small proportion, especially the professional practical courses involving students' practical ability account for even less. In order to improve the skill level of students majoring in business administration, teachers should carry out some practical training after carrying out the basic theoretical teaching content. Teachers can also use information technology to simulate some cases of business management scheme design, and then let students participate in case study and scheme production training or competition activities. In this way, students' interest in learning can be greatly improved, and then their practical ability can be improved.

\section{Conclusions}

Under the background of mobile Internet, it has become an important challenge for business administration majors in colleges and universities to cultivate comprehensive talents with practical ability and decision-making ability, and the reform and continuous improvement of practical teaching are imperative. In the reform of practical teaching, it is necessary to change the situation that teachers give priority to and students receive passively. In this case, it is necessary for colleges and universities to systematically build a growth plan system for each student, so as to effectively take students as the center and formulate practical teaching plans that meet their own conditions and meet social needs. In the era of increasingly fierce employment competition, the core of how to improve the employment ratio of business administration majors, enhance the market competitiveness of graduates of this major, and establish a good reputation of graduates of this major in enterprises and society is to enhance the core professional ability of graduates of this major. According to OBE's educational philosophy, in the evaluation process of practical teaching, business administration majors should establish a whole process, diversified and open evaluation system to realize a comprehensive, fair and objective evaluation of students' practical ability. In order to effectively meet the actual needs of society, colleges and universities should take the initiative to reform the training mode of information management professionals based on OBE concept, so as to improve students' professional quality and employment competitiveness. 


\section{Acknowledgements}

General topic of Guangdong Higher Vocational Education Research Association in 2019 "Talent training mode research of Business Administration base on OBE" (GDGZ19Y020) Chen Hongshou.

\section{References}

1. Wang Y, Mou D, Xia J. Construction of guidance courses for business administration in colleges and universities based on the OBE concept. Education Modernization 2018; 5(53): 182-183.

2. Liu B, Song Z. Teaching reform of "Food Business Management" based on OBE teaching management. Comparative study of cultural innovation 2018; 52(16): 115-116.

3. Cao Ying. Design of a comprehensive assessment system for higher vocational management courses under the OBE perspective. Neijiang Technology 2019; 299(10): 46-47.

4. Hu M, Wang G. Research on application-oriented undergraduate teaching team construction based on OBE model. Manager 2017; (23): 227-228.

5. Yao S, Bian J, Wang $\mathrm{C}$, et al. Teaching reform of chemical engineering technology economics course based on OBE-CDIO education model. Educational Modernization 2020; 7(16): 35-37.

6. Zhou C, Liu Y, Yao D, et al. Research on the innovation model of undergraduate graduation practice under the OBE concept. Experimental Technology and Management 2016; 33(10): 19-22.

7. He Z, Zheng Y, Zhou K. Exploration of electrical engineering talent training based on OBE concept and FH model.

8. Liu X. Research on "Database Technology and Application" curriculum reform based on OBE concept. Rural Economy and Technology 2020; 485(9): 399-400.

9. Shen H, Tang Y, Li R. The effective path of accounting professional construction and implementation based on the OBE concept. Educational Modernization 2019; 6(64): 95-96.

10. Yang Z, Tong J, Zhu C, et al. Exploration of business management talent training model based on dynamic process. Laboratory research and exploration 2015; 34(3): 266-268.

11. Wu F. Research on the cultivation of business management talents from the employment perspective. Science and Technology Entrepreneurship Monthly 2015; 28(8): 33-34. 